\title{
Multiple disappearing spinal lesions
}

\section{Daniel Walker ${ }^{1}$ (D) Zaid Jibri $^{1,2}$}

Published online: 13 December 2019

(C) ISS 2019

\section{Prompt}

A 45-year-old man with metastatic non-small cell lung cancer he presents with shortness of breath, and CT pulmonary angiogram (CTPA) is performed (Fig. 2a, b).

undergoes standard restaging CT (Fig. 1a-c). One month later,
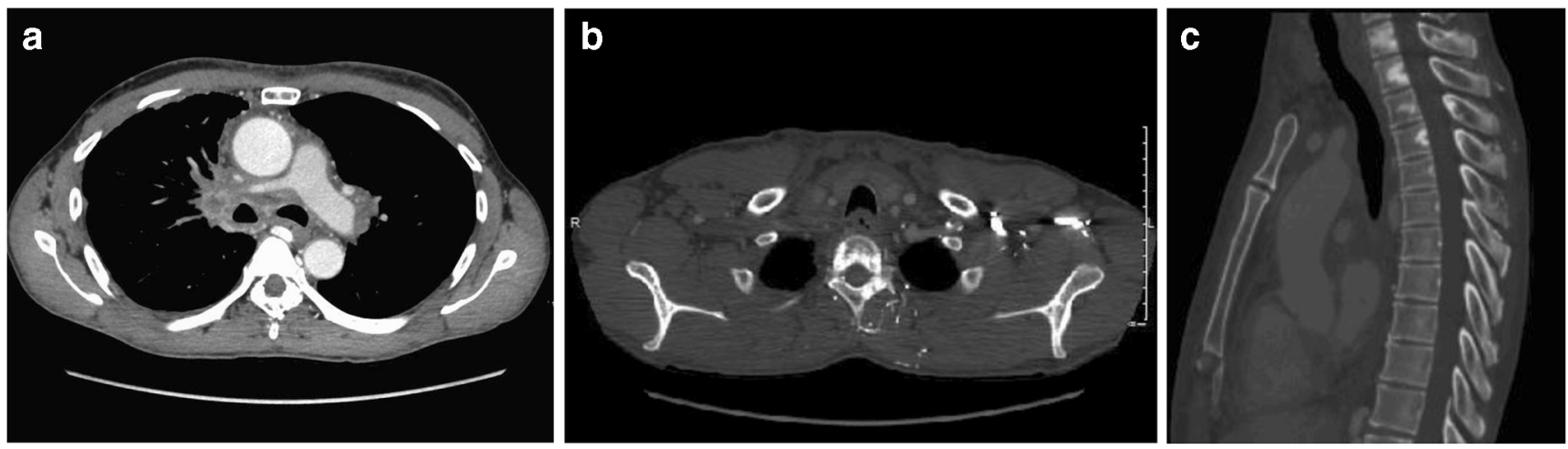

Fig. 1 a-c Arterial phase contrast enhanced CT at restaging presentation

Fig. 2 a, b Pulmonary arterial phase CT 1 month later
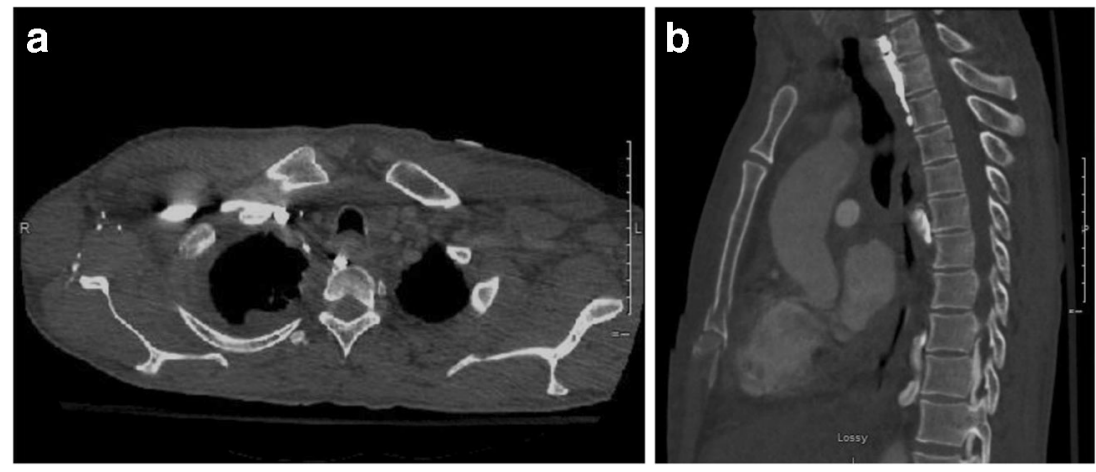

The diagnoses can be found at https://doi.org/10.1007/s00256-019-03358-y

Daniel Walker

dwalk085@uottawa.ca; dawalker@toh.ca

\section{Zaid Jibri}

zjibri@toh.ca

1 Department of Radiology, University of Ottawa, Ottawa, Canada

2 Department of Medical Imaging, The Ottawa Hospital,

Ottawa, Canada 